\title{
A virtude da dulia (hONRa) EM Tomás de Aquino
}

\author{
Felipe de Azevedo Ramos ${ }^{1}$
}

\begin{abstract}
Resumo: A honra foi amplamente tratada por diversos autores antigos, tais como Aristóteles e Cícero. No medievo, Tomás de Aquino retoma alguns temas da Antiguidade, oferecendo uma formulação nova. Para isso, ele se serve do conceito de dulia, superando o tradicional binômio com a latria. Na realidade, ele reputa à dulia uma virtude anexa à justiça que visa prestar honras ou homenagens aos homens excelentes, em particular aos virtuosos. De fato, o Estagirita já considerava a honra como um "prêmio da virtude". Nesse contexto, se percorre todo corpus thomisticum para analisar o conceito de dulia e de honra, quando esta se refere ao assunto tratado. Para isso, se pergunta o que é a dulia propriamente, a quem deve ela ser prestada, se a honra pode ou deve ser desejada, o papel da magnanimidade, como e para que se honra. A proposta tomasiana poderia trazer um novo olhar a respeito da temática, infelizmente um pouco esquecida nos dias de hoje.
\end{abstract}

Palavras-chave: Dulia. Honra. Magnanimidade. Justiça. Virtude.

Hoje em dia, quando se fala em honra, naturalmente vem à mente a boa conduta ou a probidade. Uma pessoa honrada seria fiel, reta e honesta. Todavia, ao tomar o termo no seu sentido originário, como entre os autores antigos (e, em parte, os medievais), a gama lexical própria ao termo "honra" (em latim: honos) é bastante ampla.

A honra, de fato, foi muito abordada pelos autores clássicos da literatura latina, sobretudo Cícero. Aristóteles, da tradição grega, representa o maior expoente sobre o tema. Na Idade Média, a questão da dulia (louvor às criaturas) se concentrou quase sempre na sua distinção da latria (louvor a Deus). A noção de honra também estava inserida nos códigos de cavalaria medievais, boa parte dependentes das noções cristãs de perfeição e pureza de intenção (OLSTHOORN, 2015, p. 26).

1 Professor de Filosofia no Instituto Filosófico Aristotélico Tomista, Mairiporã, SP - Brasil. (D) https://orcid.org/0000-0001-5635-3145 E-mail: feliperamos.br@gmail.com

Doutor em Filosofia pela Pontificia Università San Tommaso d'Aquino (Angelicum, Roma). Possui pós-graduação em Estudos Medievais (Diplôme Européen d'Études Médiévales - FIDEM).

http://dx.doi.org/10.1590/0101-3173.2019.v42esp.15.p265

This is an open-access article distributed under the terms of the Creative Commons Attribution License. 
Tomás de Aquino, numa proposta original, restaura os conceitos antigos com uma roupagem original. Ele versa sobre a dulia no contexto das honrarias (ou seja, as próprias homenagens), mas também do próprio ato de honrar, chamado também de dulia, como uma virtude anexa da justiça. $\mathrm{Na}$ filosofia contemporânea o assunto é raramente tratado, exceto quando se remonta ao pensamento antigo.

Segundo nosso parecer, a abordagem tomasiana é fundamental, pois representa a melhor síntese do passado, aliada à sua visão escolástica, sem perder a atualidade. Esse tema praticamente não é tratado pelos tomistas hodiernos, seja porque a dulia esteja circunscrita a poucas páginas da Suma, seja porque os temas anexos estejam espalhados e isolados pelo corpus thomisticum. Ou ainda porque não se trate de um assunto tão relevante para os filósofos ou mesmo pelo medo de se resvalar no que hoje se chama de "culto à personalidade".

Este estudo toma o vocábulo "dulia”, em particular, e outros termos que se referem à honra sempre dentro do conjunto do corpus thomisticum ${ }^{2}$.

Proceder-se-á sobre o assunto de modo analítico, utilizando-se das circunstâncias clássicas enumeradas por Cícero, na medida das possibilidades ${ }^{3}$.

\section{Algumas distinçóes prévias}

A justiça é definida tradicionalmente como a virtude que visa dar a cada um o que é devido. A injustiça, por sua vez, seria propriamente a violação do que pertenceria a alguém por direito. Desse modo, quando reputamos que um juiz foi injusto, por exemplo, isso significa que, diante dos fatos, ele não aplicou as leis conforme a prescrição e a hermenêutica. Outra definição clássica da justiça se extrai da Suma teológica: "A justiça é o hábito pelo qual, com vontade constante e perpétua, se dá a cada um o seu direito." 4

\footnotetext{
${ }^{2}$ As citaçôes privilegiam a Edição Leonina, quando existente (=Leon.).

3 Cf. "quis, quid, ubi, quibus auxiliis, cur, quomodo, quando" (CICERO. De inventione, I, c. 24-27 cit. in $S T, \mathrm{I}^{\mathrm{a}} \mathrm{II}^{\mathrm{ae}}$, q. 7, a. 3, co., Leon. 6, p. 66a).

${ }^{4}$ Iustitia est habitus secundum quem aliquis constanti et perpetua voluntate ius suum unicuique tribuit. (ST, $\mathrm{II}^{\mathrm{a}} \mathrm{II}^{\mathrm{ae}}$, q. 58, a. 1, co., Leon. 9, p. 9b).
} 
Na mesma Suma, o Aquinate comenta que "há virtudes que consistem

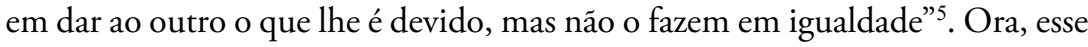
é o caso da própria virtude da justiça, a qual, de uma parte implica em certa igualdade $\left(S T, \mathrm{II}^{\mathrm{a}} \mathrm{II}^{\mathrm{ae}}\right.$, q. 57 , a. 1, co) e, de outra, possui certas açôes realizadas sem equiparação. Nesse âmbito, se encontram diversas virtudes anexas ${ }^{6}$, tais como: a que diz respeito à justiça prestada a Deus (virtude da religiáo), aos pais (virtude da piedade) e às pessoas em geral (virtude da observância/respeito) ${ }^{7}$. Efetivamente, não há nessas virtudes paridade entre as partes envolvidas. No tocante a esta última virtude (a observância), o Doutor Angélico apresenta duas fontes principais para a sua reflexão: Aristóteles (sobretudo pela Ética a Nicômaco) e Cícero, segundo o qual "aqueles que são superiores por alguma dignidade são cultuados e honrados” 8 .

No tocante à virtude da justiça lato sensu, se considere ainda que existem dois tipos de débito: o legal, que consiste em retribuir de acordo com a lei (por uma função); e o moral, exigido em conformidade com a honestidade da virtude. Em outros termos, alguns merecem determinada honra pelo cargo que exercem (como é o caso do governante); outros pela virtude ou excelência que possuem (ou ambos). Nessa esteira, seguindo Cícero, Tomás sustenta que, em relação às pessoas excelentes, é necessário ter: reverência, honra e obediência (esta última quando for o caso) $\left(S T\right.$, $\mathrm{II}^{\mathrm{a}} \mathrm{II}^{\mathrm{ae}}$, q. 80 , a. un., ad 3). Portanto, existem honras diversas para cada posto ocupado (é diferente a honra prestada ao pai, ao rei ou ao professor, etc. $\left.{ }^{9}\right)$, e honras de acordo com alguma excelência, mister a virtude, máxima merecedora de honras.

Nesse panorama, entre as virtudes anexas à justiça, se encontra propriamente a dulia (traduzida também como "honra"). Trata-se, na visão tomasiana, de uma ramificação (junto com a obediência) da virtude da

5 Sunt enim quaedam virtutes quae debitum quidem alteri reddunt, sed non possunt reddere aequale. (ST, $\mathrm{II}^{\mathrm{a}} \mathrm{II}^{\mathrm{ae}}$, q. 80, a. un., co., Leon. 9, p. 174b).

6 Denominam-se "anexas", pois: "Primeiro, que essas virtudes devem ter algo comum com a principal; em segundo lugar, que lhes falta algo da virtude principal na sua perfeita natureza." [Primo quidem, quod virtutes illae in aliquo cum principali virtute conveniant; secundo, quod in aliquo deficiant a perfecta ratione ipsius.] (ST, $\mathrm{II}^{\mathrm{a}} \mathrm{II}^{\mathrm{ae}}$, q. 80, a. un., co., Leon. 9, p. 174a).

7 Sobre isso, cf. CICERO. De inventione, II, 161.

${ }^{8}$ Homines aliqua dignitate antecedentes quodam cultu et honore dignantur. (CICERO. De invent. Rhet., II, c. 53, ed. G. Friedrich, Lipsiae, 1908, p. 230, 1. 29-30, cit. in $S T$, $\mathrm{II}^{\mathrm{a}} \mathrm{II}^{\mathrm{ae}}$, q. 80, a. un., co., Leon. 9, p. 373a).

${ }^{9} \mathrm{Cf}$. Ideo oportet quod sit alia ratio honoris, et alia virtus secundum speciem, quae diversos honores exhibet. Non enim idem honor debetur patri, regi et magistro, et sic de aliis, ut dicit Philosophus in IX Eth. [2, 1165a21-29; 1.2]. (In Sent., III, d. 9, q. 2, a. 2, co., Mand. 3, 322). 
observância/respeito ${ }^{10}$. Ou melhor, a honra é um dos elementos da observância, isto é, uma das formas de demonstrar respeito, sempre no quadro da virtude da justiça.

Para bem compreender a terminologia tomasiana, convém fazer antes uma distinção fundamental. A palavra "dulia” é com mais frequência utilizada no corpus thomisticum em referência ao binômio latria-dulia, conforme a especificação de Pedro Lombardo (†1160). No cristianismo, a latria alude à veneraçáo devida a Deus ${ }^{11}$, e a dulia à veneração prestada às criaturas excelentes (em particular aos santos) (ST, $\mathrm{II}^{\mathrm{a}} \mathrm{II}^{\mathrm{ae}}$, q. 84, a. 1, ad 1).

No quadro das virtudes sociais, Tomás dedica uma breve, mas densa questão à dulia na Suma teológica $\left(\mathrm{II}^{\mathrm{a}} \mathrm{II}^{\mathrm{ae}}\right.$, q. 103). Embora ele trate aí também dessa virtude do ângulo religioso (latria-dulia), este trabalho se concentrará apenas nos aspectos que dizem respeito à honra (ou homenagem), isto é, à dignidade concreta própria da justiça distributiva, prestada aos homens dignos e de modo proporcional à sua excelência ${ }^{12}$.

\section{O QUE É A DULIA?}

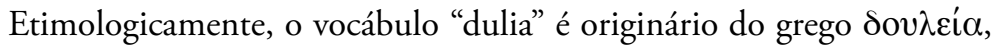
que significa "servidão"13. Transposto para a linguagem filosófica, essa virtude contém as seguintes características:

\footnotetext{
${ }^{10}$ É de notar que o termo "observância", derivado do verbo "observar", possui origem na forma com $o b+$ servo (que é cognato de palavras como: preservar, conservar, servir). "Observar" possui ainda o sentido de fixar o olhar com atenção (em alguém que merece): "Observare est aliquid anxie speculari seu notare.” (BILLUART, v. 5, p. 101). Ou seja, se refere à postura que se deveria guardar para com aqueles "que são superiores, seja pela idade, seja pela sabedoria, seja pela honra, seja por qualquer outra dignidade" (observantiam, per quam aetate aut sapientia aut honore aut aliqua dignitate antecedentes veremur et colimus). (CICERO. De inventione, II, 66, p. 230).

${ }^{11}$ Esta pertence à virtude da religiâo, enquanto presta a "devida honra" a Deus: "Ad religionem pertineat reddere honorem debitum alicui, scilicet Deo, manifestum est quod religio virtus est." (ST, $\mathrm{II}^{\mathrm{a}} \mathrm{II}^{\mathrm{ae}}$, q. 81, a. 2, co., Leon. 9, p. 179b). Cf. etiam: In Deo est omnis ratio honoris qui invenitur in creatura, sed non convertitur; ideo latria debetur sibi secundum id quod est sibi proprium; dulia autem secundum id quod est commune sibi et creaturae per analogiam. (In Sent., III, d. 9, q. 2, a. 1, ad 1, Mand. 3, p. 321).

${ }^{12}$ Cf. Et dicit quod etiam ex ratione dignitatis manifestum est quod iustum consistit in quadam proportionalitate. Sic enim aliquid dicitur esse iustum in distributionibus in quantum unicuique datur secundum dignitatem, id est prout cuique dignum est dari, in quo designatur proportionalitas quaedam, ut scilicet ita hoc sit dignum uni sicut aliud est dignum alteri. Non tamen dignitatem distributionis omnes secundum idem attendunt. (In Eth., V, 4, Leon. 47.2, p. 277-278:161-170).

${ }^{13}$ Cf. Quia per observantiam honoramus quascumque personas dignitate praecellentes: per duliam autem proprie sumptam servi suos dominos venerantur; dulia enim graece servitus dicitur. $\left(S T, \mathrm{II}^{\mathrm{a}} \mathrm{II}^{\mathrm{ae}}\right.$,
} 
A condição servil em toda a sua extensão e complexidade de suas formas, indo desde a escravidão até à domesticidade, bem integrada numa casa de família, passando pelas modalidades da servidáo. Como forma de comportamento, a dulia exprime a atitude de submissáo e de serviço, desenvolvendo-se sob duas modalidades em si essencialmente diversas, mas culturalmente e socialmente associadas na prática e no pensamento do mundo antigo, a saber: o reconhecimento de um dever de sujeição e de deferência ligado à condição servil, concebido na multiplicidade de suas realizaçóes; mas, por outro lado, em virtude da transposição espiritual e semântica, a dulia designa a honra devida à excelência e à perfeição da virtude, em particular o culto de veneraçáo prestado aos santos, aos que estão próximos de Deus, ao qual devemos em exclusividade o culto de latria. (LOYOLA, 2001-2006, v. 6, nota a, p. 544).

Alerte-se, de antemão, que Tomás de Aquino não entende que a dita dulia se referisse a algo análogo à escravidão, subserviência ou mesmo servilismo. Na realidade, como virtude social, ela alude às homenagens ou às reverências prestadas publicamente a outrem como testemunho da sua excelência ou por um bem excelente que ele possui ${ }^{14}$. Tampouco se reduz ao já mencionado binômio latria-dulia.

Como a citação acima explicita, a honra traz certo reconhecimento e deferência pela prática de um bem relevante. Isso porque seria inútil (e até mesmo injusto) honrar alguém por um bem supérfluo ou, pior ainda, por um mal praticado. Para Tomás, isso seria configurado como um falso testemunho, isto é, quando se louva quem não merece ${ }^{15}$. E até se cairia facilmente na hipocrisia ou na adulação. É por essa razão que se deve honrar antes a verdade do que as pessoas ${ }^{16}$, conforme o clássico adágio amicus Plato sed magis amica veritas (TARÁN, 1984). Em síntese, a honra que não se baseia na verdade não é verdadeira honra.

q. 103, a. 3, co., Leon. 9, p. 379b).

${ }^{14}$ Cf. e.g. ST, $\mathrm{I}^{\mathrm{a}} \mathrm{II}^{\mathrm{ae}}$, q. 2, a. 2, co.; In Eth., IV, 9 (Leon. 47.2, p. 231:100-101: "Honor enim est quaedam reverentia quae debetur superexcellenti bono." Quanto maior esse bem maior deveria ser a honra: "Omne autem illud quod superexcedit in bono est magis honorabile." (In Eth., IV, 9, Leon. 47.2, p. 231:98-99).

15 Cf. Cum honor sit reuerentia alicui exhibita in testimonium uirtutis, falsum testimonium de eo proferret, si quis eum obtentu propriae personae honoraret. (QQ VIII, q. 4, a. 2, co., grifo nosso, Leon. 25.1, p. 68:23-25).

${ }^{16}$ Cf. Veritas autem est amicus superexcellens cui debetur reverentia honoris. (In Eth., I, 6, Leon. 47.1, p. 22:63-64). 
Seria também inapropriado honrar alguém por um cargo que não ocupa. Esse assunto, o Aquinate ilustra com o seguinte exemplo: se alguém fosse honrado como governante no lugar do legítimo ocupante (um impostor), seria ele enquadrado pelo crime de lesa-majestade ${ }^{17}$. Em suma, a honra se presta apenas a quem a merece.

Pois bem, o sentido de dulia que se pretende abordar é cognato à ideia de honra, que ocorre por dever de justiça, seja devido a uma excelência (sobretudo a virtude), seja pelo cargo que ocupa. Este é o caso, por exemplo, dos súditos em relação ao governante, dos discípulos ao mestre, dos soldados ao comandante, etc. Entretanto, essas relaçóes se referem mais especificamente à virtude da observância (ou respeito), tratada numa questão à parte $\left(S T, \mathrm{II}^{\mathrm{a}} \mathrm{II}^{\mathrm{ae}}\right.$, q. 102), pela qual "se prestam honras às pessoas constituídas em dignidade" (a. 1, co.). Na realidade, como já se aludiu, a honra nada mais é que uma forma externa de prestar respeito.

A seguir se versará, sobretudo, acerca da honra prestada aos virtuosos ou a certo bem excelente do honrado (honoratus). De fato, a dulia reconhece antes de tudo a virtude no outro, conforme a formulação aristotélico-tomasiana: "A honra é a demonstração da reverência em testemunho da virtude" 18 , referindose ao próprio bem honrado ${ }^{19}$. Nesse sentido, quando dirigida a qualquer homem por sua excelência, tal honra contém algo da espécie da virtude da piedade e algo da observância (BILLUART, v. 5, p. 102).

Para entender bem essa virtude, é mister analisá-la do ponto de vista subjetivo, isto é, quem presta a dulia e quem a recebe.

\section{A Quem deVe Ser Prestada a DUlia?}

Ao comentar a Ética a Nicômaco, o mestre dominicano explicita que a honra é requerida não somente às pessoas constituídas em dignidade, mas

\footnotetext{
${ }^{17} \mathrm{Cf}$. Hoc etiam videmus in omni republica observari, quod summum rectorem aliquo signo singulari honorant, quod cuicumque alteri deferretur, esset crimen laesae maiestatis. ( $S T$, $\mathrm{II}^{\mathrm{a}} \mathrm{II}^{\mathrm{ae}}$, q. 85 , a. 2 , co., Leon. 9, p. 217b).

${ }^{18}$ Cf. Honor enim est exhibitione reverentiae in testimonium virtutis: ut potest accipi a Philosopho, in I Ethic. (ST, $\mathrm{II}^{\mathrm{a}} \mathrm{II}^{\mathrm{ae}}$, q. 103, a. 1, obj. 1, Leon. 9, p. 377a). Cf. etiam: ARISTÓTELES. Ethica Nicomachea, I, 3 (1095b26-30); In Sent., IV, d. 49, q. 4, a. 5, qc. 1, ad 7.

${ }^{19} \mathrm{Cf}$. Honor respicit proprium bonum honorati: defertur enim alicui in testimonium propriae virtutis. $\left(S T, \mathrm{II}^{\mathrm{a}} \mathrm{II}^{\mathrm{ae}}\right.$, q. 25, a. 1, ad 2, Leon. 8, p. 197b).
} 
também para premiar os próprios "atos do virtuoso" (e o próprio virtuoso) ${ }^{20}$. Aquele que é iníquo, comenta Aristóteles, não é digno de honra, pois esta deve ser o "prêmio da virtude" (Ética a Nicômaco, IV, 3, 1123b31-1124a1)21. Ora, como a virtude é conquistada pelo exercício da inteligência e da vontade, Tomás descarta a hipótese de honrar seres irracionais ou inanimados, a não ser que façam referência a um ser racional (por exemplo, honrando a imagem ou a roupa de um rei, para indiretamente louvá-lo) ( $S T, \mathrm{III}^{\mathrm{a}}$, q. 25 , a. 4, co.).

De modo geral, todos os seres humanos, por sua própria natureza e dignidade, são passíveis de reverência (CARPINTEIRO, 2016, p. 115). Por isso se fala em "dignidade humana", a qual deve ser sempre respeitada e honrada. Contudo, a honra em sentido estrito supera o universalismo dessa dignidade, pois seria injusto premiar igualmente a todos. Pois bem, a maior excelência do homem é a virtude, ao torná-lo mais perfeitamente homem. Ora, se prestam honras sobretudo aos virtuosos, como forma de premiá-los. Enquanto a observância/respeito (ou ainda a obediência) estão ligados sempre a uma hierarquia (de baixo para cima), a dulia pode ser prestada em sentido inverso, isto é, de um superior para um inferior ${ }^{22}$. Por exemplo, o mestre pode honrar um discípulo com uma medalha, ao passo que a obediência é sempre monodirecional. Ou seja, se louva o inferior náo porque seja superior em dignidade (pelo cargo), mas porque possui alguma excelência (da virtude) em grau eminente ${ }^{23}$. Por isso, a dulia e a reverência não estariam necessariamente ligadas ao temor, como defendia Filipe, o Chanceler $(\dagger 1236)^{24}$.

${ }^{20} \mathrm{Cf}$. Honor etiam est quem requirunt hi qui sunt in dignitate; honore etiam praemiantur virtuosi actus. (In Eth., IV, 8, Leon. 47.2, p. 227:119-121).

${ }^{21}$ Cit. in $S T$, $\mathrm{II}^{\mathrm{a}} \mathrm{II}^{\text {ae }}$, q. 103, a. 1, obj. 2. Cf. etiam: Ibid., $\mathrm{II}^{\mathrm{a}} \mathrm{II}^{\text {ae }}$, q. 75, a. 2, co. CICERO, Marcus Tullius. Brutus, 281 (p. 242); Epistulae ad familiares, 10, 10, 2.

${ }^{22} \mathrm{Cf}$. Respondeo dicendum quod, sicut dictum est, honor nihil est aliud quam quaedam protestatio de excellentia bonitatis alicuius. Potest autem alicuius excellentia considerari non solum per comparationem ad honorantem, ut scilicet sit excellentior eo qui honoratur, sed etiam secundum se, vel per comparationem ad aliquos alios. Et secundum hoc, honor semper debetur alicui propter aliquam excellentiam vel superioritatem. (ST, $\mathrm{II}^{\mathrm{a}} \mathrm{II}^{\mathrm{ae}}$, q. 103, a. 2, co., Leon. 9, p. 378a).

${ }^{23} \mathrm{Cf}$. Ad quartum dicendum quod privatae personae interdum honorantur a regibus, non quia sint eis superiores secundum ordinem dignitatis, sed propter aliquam excellentiam virtutis ipsarum. Et secundum hoc honorati sunt Tobias et Mardochaeus a regibus. $\left(S T, \mathrm{II}^{\mathrm{a}} \mathrm{II}^{\mathrm{ae}}\right.$, q. 103 , a. 2, ad 4, Leon. 9, p. 378b).

${ }^{24}$ Cf. PHILIPPUS CANCELLARIUS. Summa de bono, De iustitia, q. VII, 2 (ed. Wicki, v. 2, p. 990). 
A causa da honra (causa honoris) é a razão pela qual ela é prestada por alguma excelência ${ }^{25}$. Assim, se premia aqueles que se destacam no esporte ou nas artes; se conferem galardóes a quem se sobressai nas ciências; se instituem comendas ou insígnias (ou seja, um sinal) para condecorar atos heroicos ou modelares (ornamenta honoris) ${ }^{26}$. Vale destacar, porém, que Tomás julga que é obrigatório prestar honras à virtude e ao virtuoso (quanto às outras honras, seria apenas conveniente) $)^{27}$.

A honra em sentido pleno se presta, pois, apenas à virtude. Antes, se confere a honra aos melhores, ou seja, àqueles que já alcançaram o fim. ${ }^{28}$ Nesse panorama, afirma Aristóteles: "A honra é sinal de boa reputação por fazer bem; são justamente honrados, sobretudo os que têm feito o bem, eles e também o que tem a capacidade de o fazer." ${ }^{29}$ Ora, a boa reputação é conferida justamente a quem é considerado um homem de bem ou quando possui "um bem que todos, a maioria, os bons ou os prudentes o desejam" ${ }^{30}$. A honra, com efeito, compreende a dignidade, pois é merecedora dela, e traz consigo a fama, pois dela foi merecedora.

Tomando a questáo do ângulo oposto, se percebe que quem zomba (ou seja, quem desonra) o justo cairia numa falta grave, segundo a expressão do Aquinate $^{31}$. Se o homem bom é digno de honra, o homem mau simplesmente não o $\mathrm{e}^{32}$. Logo, se trataria de uma injustiça social honrar pessoas indignas, além de uma demonstração de discriminação (acepção de pessoas) ${ }^{33}$. Por isso,

${ }^{25}$ Cf. Causa autem honoris est id ex quo ille qui honoratur habet aliquam excellentiam. (ST, III, q. 25 , a. 1, Leon. 11, p. 275b).

${ }^{26}$ Sobre isso, cf. JACOTOT, 2013, p. 242.

${ }^{27} \mathrm{Cf}$. Honor est quoddam testimonium de virtute eius qui honoratur, et ideo sola virtus est debita causa honoris. (ST, $\mathrm{II}^{\mathrm{a}} \mathrm{II}^{\mathrm{ae}}$, q. 63, a. 2, co., Leon. 9, p. 65a).

${ }^{28} \mathrm{Cf}$. Honor autem est etiam optimorum, quae non ordinantur ad finem, sed iam sunt in fine; ut patet per Philosophum, in I Ethic. (ST, $\mathrm{II}^{\mathrm{a}} \mathrm{II}^{\mathrm{ae}}$, q. 103, a. 1, ad 3, Leon. 9, p. 378a).

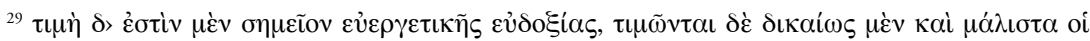

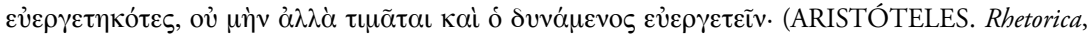
I, 5, 1361a28-30).

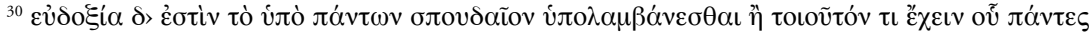

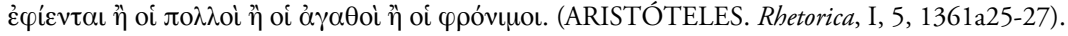

${ }^{31}$ Cf. Iustorum derisio gravis est: quia honor est virtutis praemium. (ST, $\mathrm{II}^{\mathrm{a}} \mathrm{II}^{\mathrm{ae}}$, q. 75, a. 2, co., Leon. 9, p. 142b).

${ }^{32}$ Cf. Si sit malus, non erit dignus honore, nam honor est praemium virtutis. (In Eth., IV, 8, Leon. 47.2, p. 228:197-199).

${ }^{33} \mathrm{Cf}$. Et pari ratione, si aliquis honoretur propter alias causas quae non faciunt dignum honore, quod pertinet ad acceptionem personarum. (ST, $\mathrm{II}^{\mathrm{a}} \mathrm{II}^{\mathrm{ae}}$, q. 63, a. 3, s.c., Leon. 9, p. 65a). 
se reitere, a honra é prestada apenas a quem merece, ou seja, aos "honestos", em razão de certos méritos (JACOTOT, 2013, p. 299). E é esse, aliás, o sentido etimológico de "honesto" (honestum), a saber: ser digno de honra (honos) ${ }^{34}$, "graças à sua beleza espiritual” (propter spiritualem pulchritudinem) (ST, II ${ }^{\mathrm{a}}$ $\mathrm{II}^{\mathrm{ae}}$, q. 145 , a. 3, co).

Por fim, se esclareça que a dulia se encontra no sujeito que presta homenagens, pois dita virtude "não está naquele que é honrado, porém mais naquele que honra, que reverencia o honrado, como diz o Filósofo no livro I da Etica" 35 . Francisco de Victoria comenta que a honra está subjetivamente naquele que presta honras, e não em quem as recebe, pois é sinal da excelência do outro, como seria o caso de prestar reverência com uma genuflexão, por exemplo (para Tomás, esse sinal, bem como a prostração, não se reserva apenas para Deus pela latria) ${ }^{36}$. Aquele que é honrado (honoratus), porém, recebe uma "espécie de sinal de bondade" por meio da honra ${ }^{37}$.

\section{A honra deVe Ser desejada?}

Se a honra, como foi esclarecido, é "prêmio da virtude", então ela há de ser desejada?

Antes de tudo, é mister frisar que a honra não pode ser o fim pelo qual os virtuosos agem, "mas eles recebem dos homens a honra como prêmio, como se não houvesse coisa alguma melhor para dar. O verdadeiro prêmio da virtude é a bem-aventurança [beatitudo], em vista da qual os virtuosos agem. Se agem por causa da honra, já não será virtude, mas ambição." ${ }^{38}$ A ambição, com

\footnotetext{
${ }^{34}$ A sua etimologia deriva de honos (honra), cuja semântica pode variar desde o fato de ser honorável até o ser moralmente bom (JACOTOT, 2013, p. 117), o qual prevalece hoje nas línguas vernáculas derivadas do latim. Cf. Isidorus dicit, honestas dicitur quasi honoris status. Unde ex hoc videtur aliquid dici honestum, quod est honore dignum. (ST, $\mathrm{II}^{\mathrm{a}} \mathrm{II}^{\mathrm{ae}}$, q. 145, a. 1, co., Leon. 10, p. 146a).

${ }^{35}$ Honor autem non est in eo qui honoratur, sed magis in honorante, qui reverentiam exhibet honorato, ut Philosophus dicit in I Ethic. (ST, $\mathrm{I}^{\mathrm{a}} \mathrm{II}^{\text {ae }}$, q. 2, a. 2, s.c., Leon. 6, p. 18a). Cf. etiam: SCG, III, cap. 28, n. 3.

${ }^{36} \mathrm{Cf}$. Honor est subjetive in honorante, quia est testimonium, est signum excellentiae alterius, ut genuflexio. (VICTORIA, 1937, p. 196). Inter alia quae ad latriam pertinent, singulare videtur esse sacrificium: nam genuflexiones, prostrationes, et alia huiusmodi honoris indicia, etiam hominibus exhiberi possunt, licet alia intentione quam Deo. (SCG, III, cap. 120, n. 9, Leon. 14, p. 373a).

${ }^{37}$ Cf. Honor enim est quoddam signum bonitatis eius qui honoratur. (In Eth., VIII, 8, Leon. 47.2, p. 468:33-35).

${ }^{38}$ Honor non est praemium virtutis propter quod virtuosi operantur, sed accipiunt honorem ab hominibus loco praemii, quasi a non habentibus aliquid maius ad dandum. Verum autem praemium
} 
efeito, é definida pelo Aquinate como "apetite desordenado pelas honras"39. Ela se opóe à virtude da magnanimidade, que emprega as honras de modo ordenado, conforme se elucidará mais adiante ${ }^{40}$.

Portanto, a recompensa que os virtuosos devem aspirar é a bemaventurança, verdadeiro fim da vida humana. $\mathrm{Na}$ realidade, a honra é prêmio da virtude por parte daquele que honra, pois "não há nada melhor que a honra para recompensar o homem virtuoso" ${ }^{41}$. Dita retribuição é escalonada, isto é, de acordo com a quantidade e a qualidade das obras virtuosas e dos benefícios $\operatorname{prestados}^{42}$.

À primeira vista, pois, parece que não há um mal intrínseco em desejar honras, desde que de modo equilibrado, ou seja, sem ambiçóes. O problema se encontra propriamente na cupidez pelas honras, quando essas nos desviam do fim (a bem-aventurança/felicidade). Destarte, a própria "felicidade está entre os bens a serem honrados, pois é um bem perfeito" ${ }^{3}$. Ou seja, se honram os bons pelo bem que eles têm, isto é, antes de tudo a felicidade como maior dos bens. E isso ocorre precisamente pela prática do bem.

Como se esclareceu, a honra está circunscrita ao reconhecimento prestado por alguém em testemunho da excelência de outrem. Logo, a honra, em si, não torna ninguém melhor ${ }^{44}$. De fato, a história está repleta de exemplos de personagens que foram honrados de modo exagerado e sem devidos merecimentos (injustamente). Baseando-se na jactância, a honra, nesse caso,

virtutis est ipsa beatitudo, propter quam virtuosi operantur. Si autem propter honorem operarentur, iam non esset virtus, sed magis ambitio. (ST, $\mathrm{I}^{\mathrm{a}} \mathrm{II}^{\text {ae }}$, q. 2, a. 2, ad 1, grifo nosso, Leon. 6, p. 18a-b).

${ }^{39}$ Cf. Ambitio importat inordinatum appetitum honoris. (ST, II ${ }^{\mathrm{a}} \mathrm{II}^{\mathrm{a}}$, q. 131, a. 2, co., Leon. 10, p. 76a). Cf. etiam: Ibid, III', q. 41, a. 4, ad 3.

${ }^{40} \mathrm{Cf}$. Magnanimitas autem est circa honores, et utitur eis secundum quod oportet. Unde manifestum est quod ambitio opponitur magnanimitati sicut inordinatum ordinato. (ST, $\mathrm{II}^{\mathrm{a}} \mathrm{II}^{\mathrm{ae}}$, q. 131 , a. 2, co., Leon. 10, p. 76a).

${ }^{41}$ Cf. cit. completa: Ad secundum dicendum quod honor non est praemium virtutis quoad ipsum virtuosum, ut scilicet hoc pro praemio expetere debeat, sed pro praemio expetit beatitudinem, quae est finis virtutis. Dicitur autem esse praemium virtutis ex parte aliorum, qui non habent aliquid maius quod virtuoso retribuant quam honorem. (ST, $\mathrm{II}^{\mathrm{a}} \mathrm{II}^{\mathrm{ae}}$, q. 131, a. 1, ad 2, Leon 10, p. 74b).

${ }^{42}$ Cf. Ideo superexcellenti debet dari plus de honore quia honor est propria retributio pro operibus virtutis et pro beneficiis praestitis. (In Eth., VIII, 14, Leon. 47.2, p. 496:60-63).

${ }_{33}$ Felicitas est de numero honorabilium, eo quod est quoddam bonum perfectum. (In Eth., I, 18, Leon. 47.1, p. 66:143-145).

${ }^{44} \mathrm{Cf}$. Ad secundum dicendum quod honor debetur Deo et excellentissimis, in signum vel testimonium excellentiae praeexistentis, non quod ipse honor faciat eos excelentes. (ST, $\mathrm{I}^{\mathrm{a}} \mathrm{II}^{\mathrm{ae}}$, q. 2, a. 2, ad 2, Leon. 6, p. 18b). 
pode até acentuar mais o vício (como foi o caso de muitos déspotas), segundo as célebres expressóes de Públio Siro: honos honestum decorat, inhonestum notat (H24, p. 48) e loco ignominiae est apud indignum dignitas (L1, p. 56). Contudo, Francisco de Victoria (1937, p. 197) insere uma exceção peculiar: é possível elogiar, por exemplo, a fortaleza de um assassino ou a astúcia de um advogado, desde que não se concentre na malícia (ratio malitiae) desses atos (o que na prática, diga-se, é bem difícil).

$\mathrm{Na}$ realidade, para Tomás, os homens desejam (ou deveriam desejar) a honra como bem anexo (per accidens) da felicidade, que é desejada naturalmente. Ademais, "buscam ser honrados pelos sábios, por cujos juízos se julgam excelentes e felizes” ${ }^{45}$. Em outras palavras, a honra é prestada de modo apropriado sobretudo pelos virtuosos, e é deles que se deveriam originar as honras mais adequadas.

$\mathrm{Na}$ visão dos estoicos, porém, as honras sempre empanariam a virtude, e, portanto, não deveriam ser em absoluto almejadas. Platão também reputava que nenhum homem bom deveria buscar honras, pois se trataria de ambição (Respublica, I, 347b). Cícero defende, por sua vez, que essa visão é na prática impossível e até perigosa (OLSTHOORN, 2005, p. 186). Tudo somado, "sentir-se honrado", como popularmente se diz, não é um ato necessariamente soberbo, isto é, desejar a honra não é algo per se egoístico, como queria Hobbes (OLSTHOORN, 2005, p. 193).

Não obstante isso, convém evidenciar que as honras podem ser de fato contrárias à reta razão ou à ordem. $\mathrm{O}$ Aquinate enumera três maneiras: 1) quando se vê reconhecida uma excelência que o indivíduo não possui; 2) quando alguém deseja a honra para si, sem se reportar a Deus (por participação na excelência); 3) quando se deseja a honra pela honra, sem colocá-la no âmbito da utilidade dos demais (pelo bem comum). Tudo isso se enquadraria de alguma forma na deformação da honra, isto é, na ambição ${ }^{46}$. Ora, esta é no fundo uma nervura do egoísmo e do orgulho, quando se retém para si honras

\footnotetext{
${ }^{45}$ Ad tertium dicendum quod ex naturali desiderio beatitudinis, quam consequitur honor, ut dictum est, contingit quod homines maxime honorem desiderant. Unde quaerunt homines maxime honorari a sapientibus, quorum iudicio credunt se esse excellentes vel felices. $\left(S T, \mathrm{I}^{\mathrm{a}} \mathrm{II}^{\mathrm{ae}}, \mathrm{q}\right.$. 2, a. 2, ad 3, Leon. 6, p. 18b).

${ }^{46}$ Cf. Tripliciter ergo appetitum honoris contingit esse inordinatum. Uno modo, per hoc quod aliquis appetit testimonium de excellentia quam non habet, quod est appetere honorem supra suam proportionem. Alio modo, per hoc quod honorem sibi cupit non referendo in Deum. Tertio modo, per hoc quod appetitus eius in ipso honore quiescit, non referens honorem ad utilitatem aliorum. Ambitio autem importat inordinatum appetitum honoris. $\left(S T, \mathrm{II}^{\mathrm{a}} \mathrm{II}^{\text {ae }}\right.$, q. 131, a. 1, co., Leon. 10, p. 74b).
} 
imerecidas (1), não as reporta a Deus por participação (2), nem ao bem da comunidade (3).

A honra deve ser prestada segundo um justo meio, evitando os seus contrários $^{47}$. Donde, censurarmos aqueles que desejam a honra exageradamente (ambição), bem como aqueles que sem razão a negam, pois acabam recusando (indiretamente) a boa obra merecedora de honras ${ }^{48}$. Nesse sentido, não seria congruente que se prestassem honras justas a alguém e este simplesmente não as aceitasse. Para o Aquinate, nem sequer os religiosos poderiam renunciar à honra legítima (ST, $\mathrm{II}^{\mathrm{a}} \mathrm{II}^{\mathrm{ae}}$, q. 186, a. 7, ad 4).

Entre todos os bens externos, não há nada melhor do que a honra ${ }^{49}$. Com efeito, no campo esportivo, por exemplo, muitos atletas preferem sacrificar a própria vitória para não perder a honra (fair play $)^{50}$. Além disso, se constata que, em geral, os homens deixam de lado muitas coisas para conquistar a honra e evitar o opróbrio (vituperium $)^{51}$. De fato, com frequência, a honra se torna a régua ética para tomar determinadas decisóes (se eu fizer isso, poderei perder a minha honra; logo, não faço). Nesse contexto, a honra é considerada o máximo bem externo, "na medida em que essas expressóes materiais são

${ }^{47} \mathrm{Cf}$. Ad primum ergo dicendum quod appetitus boni debet regulari secundum rationem, cuius regulam si transcendat, erit vitiosus. Et hoc modo vitiosum est quod aliquis honorem appetat non secundum ordinem rationis. Vituperantur autem qui non curant de honore secundum quod ratio dictat, ut scilicet vitent ea quae sunt contraria honori. (ST, II $\mathrm{II}^{\mathrm{ae}}$, q. 131, a. 1, ad 1, Leon. 10, p. 74b).

${ }^{48} \mathrm{Cf}$. Dicit ergo primo quod quandoque vituperamus philotimum, id est amatorem honoris, quasi appetat honorem magis quam oportet et unde non oportet, et similiter quandoque vituperamus eum qui non est amator honoris quasi non velit bona operari ex quibus honoretur. (In Eth., IV, 12, Leon. 47.2, p. 240:44-50).

${ }^{49}$ Cf. Unde manifestum est quod honor est optimum inter omnia exteriora bona. (In Eth., IV, 8, Leon. 47.2, p. 227:121-123). Res autem quae in usum hominis veniunt sunt res exteriores. Inter quae simpliciter maximum est honor. (ST, $\mathrm{II}^{\mathrm{a}} \mathrm{II}^{\mathrm{ae}}$, q. 129 , a. 1, co., Leon. 10, p. 57b). Cf. etiam: "Tal é a honra: a qual é efetivamente o maior dos bens exteriores" (

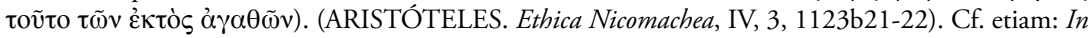
Sent., II, d. 42, q. 2, a. 4, co.

${ }^{50}$ Famoso foi o caso do maratonista espanhol Iván Fernández que, ao perceber que o queniano Abel Mutai pensava já ter cruzado a linha de chegada em primeiro lugar, indicou a ele que ainda faltava alguns metros para completar a corrida de cross-country em Navarra (2012), perdendo intencionalmente o lugar mais alto do pódio. Iván argumentou que "nos tempos atuais, vale a pena fazer gestos de honra" (cf. ARRIBAS, C. El valor de un gesto. El País, 14/12/2012. Disponível em: <https://elpais.com/ deportes/2012/12/14/actualidad/1355506756_770952.html>).

${ }^{51} \mathrm{Cf}$. Sed simpliciter et absolute magnus actus est qui consistit in optimo usu rei maximae. Res autem quae in usum hominis veniunt sunt res exteriores. Inter quae simpliciter maximum est honor, tum quia propinquissimum est virtuti, utpote testificatio quaedam existens de virtute alicuius, [...] tum etiam quia homines propter honorem consequendum et vituperium vitandum omnia alia postponunt. $\left(S T, \mathrm{II}^{\mathrm{a}} \mathrm{II}^{\mathrm{ae}}\right.$, q. 129, a. 1, co., Leon. 10, p. 57b). 
sinais demonstrativos de uma virtude excelente" 52 , e por estar muito próxima da virtude (ou do bem honesto) $\left(S T, \mathrm{II}^{\mathrm{a}} \mathrm{II}^{\mathrm{ae}} \text {, q. } 129 \text {, a. } 1, \mathrm{co}\right)^{53}$.

Do lado oposto, para se evitar a censura ou a desonra, entra em jogo o papel da vergonha (verecundia), "que é o temor da desonestidade" ${ }^{4}$. Nesse cenário, se considera ainda o autossacrifício para não perder a honra, em particular no âmbito militar (OLSTHOORN, 2005). No entanto, Aristóteles já alertava que aqueles que fazem o bem e evitam o mal só por causa da honra não podem ser considerados virtuosos. Destarte, os heróis que buscam atos heroicos simplesmente para obter a honra não são autênticos heróis ${ }^{55}$. Não por menos, a palavra latina para "virtude" (virtus) é originária de vir (varão), que indicava, nesse âmbito, a virilidade, ou melhor, a bravura e a coragem física, sinal de excelência entre os romanos (JACOTOT, 2013, p. 307).

Para compreender melhor a questão dos desejos das honras, convém agora abordar brevemente a virtude da magnanimidade.

\section{VirTUdE DA MAGNANimidADE E DULIA}

Se a dulia diz mais respeito à virtude daquele que presta honras devidas (sobretudo ao virtuoso), a magnanimidade se refere àquele que recebe honras (mormente as grandes). Essa virtude já foi tratada esmiuçadamente por vários tomistas. Ademais, como não se trata do assunto central deste trabalho, versaremos a seu respeito somente no que seja útil para a compreensão do tema proposto.

Aristóteles (Ética a Nicômaco, IV, 3, 1123b21-25) reputa que as honras devem ser prestadas (antes de tudo) àqueles que têm a "alma grande" ( $\mu \varepsilon \gamma \alpha \lambda$ ó $\psi v \chi o ́ \varsigma)$, isto é, aos magnânimos, em razão de seus méritos. Com efeito, "o magnânimo é aquele que tende para aquilo que merece uma grande

\footnotetext{
${ }^{52}$ Inquantum scilicet ipsae corporales res sunt signa demonstrativa excellentis virtutis. $\left(S T, \mathrm{II}^{\mathrm{a}} \mathrm{II}^{\mathrm{ae}}\right.$, q. 103, a. 1, co., Leon. 9, p. 377b).

${ }^{53}$ Cf. etiam: "Honor propinquum aliquid est bono honesto." (In Eth., III, 16, Leon. 47.1, p. 170:82).

${ }^{54}$ Cf. Verecundia, quae est timor turpitudinis, primo et principaliter respicit vituperium seu opprobrium. (ST, $\mathrm{II}^{\mathrm{a}} \mathrm{II}^{\text {ae }}$, q. 144 , a. 2, co., Leon. 10, p. 143a). Cf. etiam: Ibid., $\mathrm{II}^{\mathrm{a}} \mathrm{II}^{\text {ae }}$, q. 144, a. 3, co. ${ }^{55} \mathrm{Cf}$. Et tamen illi qui solum propter honorem vel bona faciunt vel mala vitant, non sunt virtuosi, ut patet per Philosophum, in III Ethic. (cap. 8, n. 1), ubi dicit quod non sunt vere fortes qui propter honorem fortia faciunt. (ST, $\mathrm{II}^{\mathrm{a}} \mathrm{II}^{\mathrm{ae}}$, q. 131, a. 1, ad 3, Leon. 10, p. 75a-b).
} 
honra" ${ }^{56}$. Na prática, o magnânimo coincide com o homem bom, pois seria incongruente chamar alguém de "magnânimo" se não fosse bom.

Tomás segue o Estagirita quando este afirma que a magnanimidade alude às honras e às desonras ${ }^{57}$. A honra é propriamente o objeto dessa virtude, ao receber grandes honras pela virtude praticada: "O magnânimo deseja realizar grandes obras em todas as virtudes, na medida em que tende para o que merece uma grande honra." ${ }^{58}$ É nesse sentido que se pode afirmar que o magnânimo se dignifica pelas honras a ele prestadas ${ }^{59}$.

Em específico, a magnanimidade trata de colocar a mediania entre a honra e a desonra ${ }^{60}$. É ainda definida como a virtude que estabelece a medida da razão para as grandes honras ${ }^{61}$. $\mathrm{Na}$ realidade, ela "diz respeito a duas coisas: à honra, como à sua matéria, e ao cumprimento de um grande feito, como a seu fim" ${ }^{2}$. A magnanimidade se refere, pois, às honras, enquanto tem a razão do difícil e do árduo, como objeto da paixão da esperança que tende ao bem árduo ${ }^{63}$.

Do ponto de vista subjetivo, o grande feito a que se refere esta virtude está atrelado à aspiração (ligada à esperança) da alma à grandeza ${ }^{64}$. Ora, entre os atos grandiosos, se encontram os bens exteriores. Como já assinalado, a

${ }^{56}$ Ad ea tendit magnanimus quae sunt magno honore digna. (ST, $\mathrm{II}^{\mathrm{a}} \mathrm{II}^{\mathrm{ae}}$, q. 129 , a. 2, co., Leon. 10 , p. 59b).

${ }^{57}$ Cf. Sed contra est quod Philosophus dicit, in IV Ethic., quod magnanimus est circa honores et inhonorationes. (ST, $\mathrm{II}^{\mathrm{a}} \mathrm{II}^{\mathrm{ae}}$, q. 129 , a. 1, s.c., Leon. 10, p. 57b).

${ }^{58}$ Magnanimus intendit magna operari in qualibet virtute, inquantum scilicet tendit ad ea quae sunt digna magno honore. (ST, $\mathrm{II}^{\mathrm{a}} \mathrm{II}^{\mathrm{ae}}$, q. 129 , a. 4, ad 1, Leon. 10, p. 64b).

${ }^{59} \mathrm{Cf}$. Magnanimus dignificat se ipsum magnis honoribus. Unde non potest esse quod aliquis malus sit magnanimus. (In Eth., IV, 8, Leon. 47.2, p. 228:199-201).

${ }^{60} \mathrm{Cf}$. Magnanimitas est medietas circa honorem et inhonorationem. (In Eth., II, 9, Leon. 47.1, p. 107:6-7).

${ }^{61}$ Cf. Magnanimitas, quae modum rationis ponit circa magnos honores, est virtus. ( $S T, \mathrm{II}^{\mathrm{a}} \mathrm{II}^{\mathrm{ae}}$, q. 129 , a. 3, co., Leon. 10, p. 61a-62b).

${ }^{62}$ Magnanimitas ad duo respicit: ad honorem quidem sicut ad materiam; sed ad aliquid magnum operandum sicut ad finem. (ST, $\mathrm{II}^{\mathrm{a}} \mathrm{II}^{\mathrm{a} e}$, q. 129 , a. 8, co., Leon. 10, p. 69b). Cf. etiam: Honor habet rationem boni ardui. ( $S T, \mathrm{II}^{\mathrm{a}} \mathrm{II}^{\text {ae }}$, q. 144 , a. 2, co., Leon. 10 , p. 143a).

${ }^{63}$ Cf. Magnanimitas consistat circa honores. - Et hoc modo honorem respicit magnanimitas, inquantum scilicet habet rationem magni vel ardui. - Magnanimitas est quidem immediate circa passionem spei, mediate autem circa honorem, sicut circa obiectum spei. (ST, $\mathrm{II}^{\mathrm{a}} \mathrm{II}^{\text {ae }}, \mathrm{q} .129$, a. 1, co.; ad 1, Leon. 10, p. 57a).

${ }^{64}$ Cf. "A magnanimidade, como o próprio nome indica, significa uma alma que tende à grandeza." [Magnanimitas ex suo nomine importat quandam extensionem animi ad magna.] (ST, $\mathrm{II}^{\mathrm{a}} \mathrm{II}^{\text {ae }}$, q. 129 , a. 1 , co., Leon. 10, p. 57a). 
honra é o maior deles, pois está intimamente ligada às virtudes, por ser delas testemunho. Conforme pontua o Aquinate: "Como a honra é a recompensa de toda virtude, por via de consequência, em razão de sua matéria, ela está em relação com todas as outras virtudes." ${ }^{65}$

O mestre dominicano ainda reforça a ideia do equilíbrio de alma daquele que recebe as honras. De um lado, é necessário que não faça nada de inconveniente para conquistá-las, nem deve estimá-las exageradamente. Assim estará mais preparado para recebê-las ${ }^{66}$. De outro lado, também mereceria censura se a pessoa honrada simplesmente desprezasse os atos de honra (dulia), conforme já se mencionou. Pois bem, aqui se insere o papel da magnanimidade, a saber, fazer tudo o que merece honra, sem sobrevalorizá$\mathrm{la}^{67}$. Na verdade, as honras trazem consigo grande responsabilidade. Por isso se cunhou na Antiguidade o brocardo ao modo de trocadilho que atribuía sempre o ônus (onus) à honra (honos) ${ }^{68}$.

Diante das honras, portanto, a questão central está em ter a devida moderação, colocando sobre elas o empenho que é devido ${ }^{69}$. Ora, tal equilíbrio é ainda mais difícil quando se trata de grandes honras ${ }^{70}$, pois, servindo-se bem destas, saberá também servir-se das pequenas. A humildade entra em jogo como moderadora das honras (CASAGRANDE, 2017, p. 234).

O magnânimo deita sua atenção nas grandes honras como se fosse digno delas, mesmo que sejam menores do que pede a justiça, pois para Tomás a virtude jamais pode ser suficientemente honorificada pelos homens (na realidade, somente por Deus). Assim, não se exalta pelas honras, nem se

\footnotetext{
${ }^{65}$ Sed quia honor est cuiuslibet virtutis praemium, ut ex supra dictis patet; ideo ex consequenti, ratione suae materiae, respicit omnes virtutes. (ST, $\mathrm{II}^{\mathrm{a}} \mathrm{II}^{\mathrm{ae}}$, q. 129 , a. 4, co., Leon. 10, p. 64b).

${ }^{66} \mathrm{Cf}$. Magnanimus est promptus magis ad possidendum quaedam bona, id est honorabilia. (In Eth., IV, 10, Leon. 47.2, p. 236:232-233).

${ }^{67} \mathrm{Cf}$. Ad tertium dicendum quod illi qui contemnunt honores hoc modo quod pro eis adipiscendis nihil inconveniens faciunt, nec eos nimis appretiantur, laudabiles sunt. Si quis autem hoc modo contemneret honores quod non curaret facere ea quae sunt digna honore, hoc vituperabile esset. Et hoc modo magnanimitas est circa honorem, ut videlicet studeat facere ea quae sunt honore digna, non tamen sic ut pro magno aestimet humanum honorem. ( $S T, \mathrm{II}^{\mathrm{a}} \mathrm{II}^{\mathrm{ae}}$, q. 129, a. 1, ad 3, Leon. 10, p. 58b).

${ }^{68} \mathrm{Cf}$. Onus est honos qui sustinet rem publicam. (VARRO, 5.73, p. 23).

${ }^{69} \mathrm{Cf}$. Laudatur enim quandoque qui amat honorem, quandoque autem qui non curat de honore, prout scilicet utrumque moderate fieri potest. ( $S T, \mathrm{II}^{\mathrm{a}} \mathrm{II}^{\mathrm{ae}}$, q. 129 , a. 2, co., Leon. 10, p. 59b).

${ }^{70} \mathrm{Cf}$. Modum in usu honoris observari oportet, qui multo difficilius observatur in magnis honoribus quam in parvis. (ST, $\mathrm{II}^{\mathrm{a}} \mathrm{II}^{\mathrm{ae}}$, q. 129 , a. 2, ad 1, Leon. 10, p. 59b).
} 
abate pelas desonras ${ }^{71}$. Não tem pretensôes em ser maior do que é, mas julga retamente segundo o seu próprio valor ${ }^{72}$.

\section{COMO SE HONRA?}

No comentário à Ética a Nicômaco, o Aquinate enumera algumas fórmulas de honorificência ao significado de honra: "A honra diz respeito a certo testemunho manifestado pela excelência de alguém, seja isso feito por meio de palavras ou por ações, como quando alguém se ajoelha ou se levanta para ele." ${ }^{\prime 3}$ Assim, diante de uma pessoa idosa, há de se demonstrar o respeito por meio da honra, levantando-se e inclinando-se, por exemplo ${ }^{74}$.

A fim de se compreender melhor a maneira que se deve portar para prestar honras, convém recordar a distinçáo tomasiana entre honra e louvor. Este último é destinado a objetos menos significativos e está englobado pela própria honra, manifestando-se apenas por palavras e com vistas a um fim diverso ${ }^{75}$.

Tomás de Aquino divide as honrarias em duas formas: as corporais (externas) e as espirituais (internas). Estas últimas são prestadas a Deus (que perscruta os coraçóes) $^{76}$, enquanto as honras humanas precisam ser exteriorizadas, pois "o testemunho só pode ser dado por certos sinais exteriores" 77 .

\footnotetext{
${ }^{71} \mathrm{Cf}$. Ad tertium dicendum quod ille qui bene utitur magnis, multo magis potest bene uti parvis. Magnanimitas ergo attendit magnos honores sicut quibus est dignus: vel etiam sicut minores his quibus est dignus, quia scilicet virtus non potest sufficienter honorari ab homine, cui debetur honor a Deo. Et ideo non extollitur ex magnis honoribus: quia non reputat eos supra se, sed magis eos contemnit. Et multo magis moderatos aut parvos. Et similiter etiam dehonorationibus non frangitur, sed eas contemnit: utpote quas reputat sibi indigne afferri. (ST, $\mathrm{II}^{\mathrm{a}} \mathrm{II}^{\mathrm{ae}}$, q. 129, a. 2, ad 3, Leon. 10, p. 60a-b).

${ }^{72}$ Cf. Eo enim quod secundum dignitatem seipsum dignificat, ut ibidem dicitur, quia scilicet se non extendit ad maiora quam dignus est. (ST, $\mathrm{II}^{\mathrm{a}} \mathrm{II}^{\mathrm{ae}}$, q. 129, a. 3, ad 1, Leon. 10, p. 62a).

${ }^{73}$ Honor enim importa quoddam testimonium manifestans excellentiam alicuius, sive hoc fiat per verba sive per facta, utpote cum aliquis genuflectit alteri vel assurgit ei. (In Eth., I, 18, Leon. 47.1, p. 65:18-21).

${ }^{74} \mathrm{Cf}$. Cuilibet seni debetur honor propter aetatem in assurgendo et inclinando eis et in huiusmodi. (In Eth., IX, 2, Leon. 47.2, p. 506-507:139-141).

${ }^{75}$ Ibid., p. 65:22-27. Cf. etiam: ST, $\mathrm{II}^{\mathrm{a}} \mathrm{II}^{\mathrm{ae}}$, q. 103, a. 1, ad 3.

${ }^{76}$ Embora esta possa ser, é claro, externa (cf. e.g. In Sent., IV, d. 1, q. 2, a. 6, qc. 3, co.).

${ }^{77} \mathrm{Cf}$. Sed quoad homines testimonium ferre nisi per aliqua signa exteriora. (ST, $\mathrm{II}^{\mathrm{a}} \mathrm{II}^{\mathrm{ae}}$, q. 103 , a. 1 , co., Leon. 9, p. 377b).
} 
Com efeito, entre os homens só é possível prestar honras por meio de sinais sensíveis, pois o interior dos coraçóes é obviamente desconhecido. Por conseguinte, Francisco de Victoria comenta que quando se percebe alguém tirando o chapéu para outro e se ajoelhando diante dele, pode saber que provavelmente se trata de "algum cavaleiro ou pessoa notável" (1937, p. 196). Nessa linha, não faria sentido conceder o Prêmio Nobel em segredo ou honrar pessoas apenas por pensamentos. Isso considerado, o Angélico Doutor ilustra algumas açóes externas próprias à honra na parte da Suma teológica dedicada à dulia:

Palavras, como quando se afirma a excelência de alguém; ou gestos, como inclinaçóes, saudaçôes e demonstraçôes deste gênero; ou ainda coisas exteriores, como oferenda de presentes ou brindes, ou levantamento de estátuas e outras manifestações do mesmo tipo. Nesse sentido, a honra consiste em sinais exteriores e corporais. ${ }^{78}$

Ademais, a honra pode ser prestada a alguém de modo indireto, por algo exterior, como por intermédio de algum objeto do honrado (como a sua roupa), por uma imagem ou mesmo um representante, pois é sempre possível honrar o conjunto por intermédio de alguma de suas partes ${ }^{79}$. Dessa forma, até os mortos podem ser honrados e sua memória celebrada ${ }^{80}$. É nessa esteira que se honra um herói de guerra não só durante a vida, mas também após a morte ${ }^{81}$.

\footnotetext{
${ }^{78}$ Verborum, puta cum aliquis ore pronuntiat excellentiam alicuius; vel factis, sicut inclinationibus, obviationibus, et aliis huiusmodi; vel etiam exterioribus rebus, puta in exenniorum vel munerum oblatione, aut imaginum institutione, vel aliis huiusmodi. Et secundum hoc, honor in signis exterioribus et corporalibus consistit. (ST, $\mathrm{II}^{\mathrm{a}} \mathrm{II}^{\text {ae }}$, q. 103, a. 1, co., Leon. 9, p. 377b).

De modo semelhante, Aristóteles (Rhetorica, I, 5, 1361a34-37) exemplifica alguns componentes da honra: "Os componentes da honra são: os sacrifícios, as inscriçóes memoriais em verso e em prosa, os privilégios, as doaçôes de terras, os principais assentos, os túmulos, as estátuas, os alimentos concedidos pelo Estado; práticas bárbaras, como a de se prosternar e ceder o lugar; e os presentes apreciados em cada país."

${ }^{79} \mathrm{Cf}$. In istis partibus honoratur totum. Per quem etiam modum aliquis homo potest honorari in aliquo exteriori, puta in veste, aut in imagine, aut in nuntio. (ST, III, q. 25, a. 1, co., Leon. 11, p. 275b).

Isso se aplicaria, no âmbito religioso, ou similar, à honra que se presta às relíquias dos santos ou mesmo de lembranças de pessoas veneráveis (cf. ibid., a. 6, ad 1).

${ }^{80} \mathrm{Cf}$. Quandoque enim mortuis aliqui honores exhibentur, sicut quod laudantur et memoria eorum celebratur, et similiter fiunt eis quaedam exhonorationes, puta cum extumulantur et eorum ossa comburuntur. (In Eth., I, 15, Leon. 47.1, p. 55:83-87).

${ }^{81}$ Cf. Fortiter in bello dimicantibus et in vita et post mortem aliqui honores exhibebantur. Honor autem est praemium virtutis. (In Eth., III, 14, Leon. 47.1, p. 161-162:165-168).
} 
$\mathrm{Na}$ realidade, as fórmulas supramencionadas dizem respeito à "reverência", isto é, à exibição da honra em testemunho da virtude ${ }^{82}$. De um lado, é pela reverência que se tem por alguém que somos levados a honrálo. De outro, a própria reverência é a finalidade da honra, ou seja, se honra alguém precisamente para que este seja reverenciado ${ }^{83}$. Contudo, a honra, vista sob o ângulo do prestígio, justamente por ser exterior, depende mais daqueles que prestam as honras do que daquele que é honrado. Por isso é que para Aristóteles, a honra não pode ser o fim do bem viver: simplesmente porque está fora do sujeito ${ }^{84}$.

\section{Para QUe SE DeVe honRar?}

O exercício da honra pode parecer para alguns uma futilidade, uma bajulação sem sentido ou mesmo simplesmente desnecessária. Ora, sendo considerada uma virtude por Tomás, ela deve ter a fortiori alguma finalidade, como, aliás, toda virtude tem.

Como já foi acenado, existe certa naturalidade na prática da dulia, de modo análogo ao respeito natural pelos pais ou pelos idosos: seni debetur veneratio ("deve-se veneração aos mais velhos"). (WALTHER, n. 28012c.). Em todas as civilizaçóes encontramos certa manifestação de respeito pelos ancestrais.

Prescindindo do egoísmo que em geral empana as ações humanas, é conforme nossa natureza que, diante de fatos honoráveis, se testemunhe homenagens à pessoa que as praticou e à própria ação em si mesma. É nessa conjuntura que se requer a humildade para bem honrar o outro ${ }^{85}$, até mesmo por um sinal de gratidão (ou reconhecimento) ${ }^{86}$. Como já esclarecido, isso vale sobretudo para louvar o virtuoso e a própria virtude unida a ele, enquanto se ordena a cumprir a obra de virtude.

\footnotetext{
${ }^{82}$ Cf. Reverentia enim consistit in exhibitione honoris qui est testimonium virtutis. (In Sent., IV, d. 49 , q. 4, a. 5, qc. 1, ad 7).

${ }^{83}$ Cf. Ad primum ergo dicendum quod reverentia non est idem quod honor, sed ex una parte est principium motivum ad honorandum, inquantum scilicet aliquis ex reverentia quam habet ad aliquem, eum honorat; ex alia vero parte est honoris finis, inquantum scilicet aliquis ad hoc honoratur ut in reverentia habeatur ab aliis. (ST, $\mathrm{II}^{\mathrm{a}} \mathrm{II}^{\mathrm{ae}}$, q. 103, a. 1, ad 1, Leon. 9, p. $\left.377 \mathrm{~b}\right)$.

${ }^{84}$ Sobre isso, cf. SOKOLOWSKI, 2014, p. 225.

${ }^{85}$ Cf. $S T$, II ${ }^{a} I^{a e}$, q. 129 , a. 3, ad 4.

${ }^{86}$ Sobre isso, cf. ROBIGLIO, 2019, p. 169.
} 
Pois bem, se louva alguém na medida em que esteja ordenado ao bem. Por exemplo, a força no combate ou a agilidade na corrida são enaltecidos porque revelam a excelência nessas atividades. Dessa forma, o atleta deseja a vitória como fim, ou seja, como bem meritório por seu esforço e, por isso mesmo, digno de ser alcançado ${ }^{87}$. De modo análogo, a honra, como bem secundário da felicidade conquistada pela posse da virtude, também pode e deve ser desejada. Não, contudo, de modo desordenado, como já se comentou. Caso contrário, se arriscaria resvalar para o vício da soberba (por meio da ambição $)^{88}$.

É nesse panorama que convém mais uma vez enquadrar a magnanimidade, ou seja, desejando a honra não como finalidade. Essa seria, na realidade, a postura dos medíocres, uma vez que eles visam apenas os bens transitórios e vãos, como a honra que passa. Na verdade, o desejo reto aqui se dirige à dignidade (ser digno de honra) e não em ter honra propriamente $^{89}$. Deseja-se, pois, a virtude, sabendo que ela traz consigo as honras prestadas pelos próprios virtuosos de modo justo. De fato, não basta ter magnanimidade; se exigem também as outras virtudes, pois ninguém é digno de ser honrado senão o virtuoso ${ }^{90}$. Em última análise, as obras virtuosas não se cumprem em vista da honra propriamente, mas para o bem da própria virtude (que é digna de honra) ${ }^{91}$.

A honra também pode servir como uma espécie de "termômetro" da alma. De fato, os homens gostam de ser honrados porque constatam que reconhecem a bondade deles (desde que seja um reto juízo, claro) ${ }^{92}$. É evidente,

${ }^{87} \mathrm{Cf}$. Laudatur virtuosus et ipsa virtus in quantum ordinatur ad exequendum opus virtutis. Secundum vero virtutem corporis laudatur aliquis quia est fortis ad pugnandum et agilis ad currendum et de aliis similibus ex hoc quod homo aliqualiter ordinatur ad aliquid quod est bonum in se et studiosum, quasi studio dignum. (In Eth., I, 18, Leon. 47.1, p. 65:54-60).

${ }^{88} \mathrm{Cf}$. Superbia inordinatus appetitus propriae excellentiae, et praecipue in dignitate vel honore. (In Sent., II, d. 5, q. 1, a. 3, co., Mand. 2, p. 148). Cf. etiam: In Sent., II, d. 42, q. 2, a. 3, ad 1.

${ }^{89} \mathrm{Cf}$. Non enim magnanimus honorem quaerit tamquam finem voluntatis suae, quia hoc nimis sibi parvum reputat, cum sit vanum et transitorium bonum; unde non multum curat honorari, sed fieri honore dignum, secundum quod honor est testimonium virtutis. (In Sent., II, d. 42, q. 2, a. 4, co., Mand. 2, p. 1081).

${ }^{90} \mathrm{Cf}$. Ad magnanimitatem praeexiguntur aliae virtutes, quia nullus potest dignificari magnis nisi virtuosus sit. (In Sent., III, d. 9, q. 1, a. 1, qc. 2, co., Mand. 3, p. 303).

${ }^{91} \mathrm{Cf}$. Cives propter illum honorem non operantur virtutis opera, sed propter bonum ipsius virtutis. (In Sent., III, d. 18, q. 1, a. 4, qc. 3, ad 4, Mand. 3, p. 571).

${ }^{2} \mathrm{Cf}$. Et propter hoc homines honorari quaerunt, quasi boni alicuius quod in eis est testimonium habere volentes. (SCG, III, cap. 28, n. 3, Leon. 14, p. 84a). 
ademais, que apenas os bons são dignos de honra. Todavia, é melhor ser apenas digno de honra do que propriamente honrado (pois os maus também recebem injustamente certas honras $)^{93}$. De fato, a honra só deveria ser prestada às pessoas dignas ${ }^{94}$. Não é por menos que Tomás utiliza a palavra "dignidade" com frequência unida à "honra", como já fazia, aliás, Cícero"

Considerando que, para Tomás, a dulia constitui uma virtude e que "toda virtude torna bom quem a tem e boa a sua obra" ${ }^{96}$, pode se concluir que quem presta homenagens conforme a justiça se beneficia por si mesmo, pois "pagar o devido a alguém tem a razão de bem" (justiça) ${ }^{97}$. Reitere-se, porém, que a honra não pode ser o fim último do homem, que é a felicidade. De fato, a pessoa honrada não está em operação, mas está no outro que honra ${ }^{98}$.

Num plano mais alto, para o Aquinate, existe sempre uma participação em Deus nas honras prestadas. Ademais, as honras fazem notar aos outros determinada excelência participativa, para que também tirem proveito dela de alguma forma. Dessa maneira, o reconhecimento por parte dos outros de dita excelência deve lhe ser agradável na medida em que é útil aos demais ${ }^{99}$. E a grandeza da honra consiste precisamente no fato de que é um testemunho prestado à virtude, embora nunca seja uma recompensa suficiente (no âmbito participativo), conforme já defendia Aristóteles (Ética a Nicômaco, IV, 7, $1124 \mathrm{a} 7-9)^{100}$.

\footnotetext{
${ }^{93} \mathrm{Cf}$. Esse dignum honore non potest nisi bonis inesse. Honorari autem possunt etiam mali. Melius est igitur fieri honore dignum quam honorari. (SCG, III, cap. 28, n. 5, Leon. 14, p. 84b).

${ }^{94}$ Cf. Honor exhibetur personis in dignitate constitutis. (ST, $\mathrm{II}^{\mathrm{a}} \mathrm{II}^{\mathrm{ae}}$, q. 102, a. 1, co., Leon. 9, p. 373b).

${ }^{95}$ Cf. e.g.: Dignitas est alicuius honesta et cultu et honore et uerecundia digna auctoritas. (CICERO. De inventione, II, 166).

${ }^{96}$ Virtus est quae bonum facit habentem et opus eius bonum reddit. (ST, $\mathrm{II}^{\mathrm{a}} \mathrm{II}^{\mathrm{ae}}$, q. 81 , a. 2, co., Leon. 9, p. 179a).

${ }^{97}$ Reddere debitum alicui habet rationem boni. (ST, $\mathrm{II}^{\mathrm{a}} \mathrm{II}$ ae , q. 81, a. 2, co., Leon. 9, p. 179a).

${ }^{98} \mathrm{Cf}$. Honor autem hominis non consistit in sua operatione, sed alterius ad ipsum, qui ei reverentiam exhibet. Non est igitur felicitas hominis in honoribus ponenda. [...] Hoc autem quod honorem assequatur, non est in potestate hominis, sed magis in potestate honorantis. Non est igitur in honoribus felicitas humana ponenda. (SCG, III, cap. 28, n. 3-4, Leon. 14, p. 84b).

${ }^{99}$ Cf. Primo quidem, quod id secundum quod homo excellit, non habet homo a seipso, sed est quasi quiddam divinum in eo. Et ideo ex hoc non debetur principaliter sibi honor, sed Deo. Secundo considerandum est quod id in quo homo excellit, datur homini a Deo ut ex eo aliis prosit. Unde intantum debet homini placere testimonium suae excellentiae quod ab aliis exhibetur, inquantum ex hoc paratur sibi via ad hoc quod aliis prosit. (ST, $\mathrm{II}^{\mathrm{a}} \mathrm{II}^{\mathrm{ae}}$, q. 131, a. 1, co., Leon. 10, p. 74a).

${ }^{100}$ Cf. Qui ex hoc ipso magnitudinem habet quod perhibet testimonium virtuti. Unde patet quod non est sufficiens praemium, ut dicitur in IV Ethic. (ST, $\mathrm{II}^{\mathrm{a}} \mathrm{II}^{\mathrm{ae}}$, q. 131, a. 1, ad 2, Leon. 10, p. 74b).
} 
A honra demonstra, pois, para a sociedade ou para um conjunto de indivíduos, que determinada ação serve de exemplo a ser imitado. É uma forma de esplendor da virtude. É nessa direção que "é um dever manifestar o bem e o belo", pelo que a honra é comparada à luz, não colocada sob um móvel, mas sobre um candeeiro para ser vista ${ }^{101}$. O honrado se torna, portanto, uma figura pública, visível a todos. Ora, aqui se conjuga o papel da magnificência, reverenciando alguém ou uma obra, "cuja honra possa ressaltar sobre toda a comunidade" 102 .

O Doutor Angélico pontua ainda, citando a Retórica de Aristóteles (I, 9, 1366b3-6), que honramos mais os fortes e os justos, pois a fortaleza e a justiça dizem respeito ao bem comum (ao passo que a temperança é individual) ${ }^{103}$. E se numa cidade, a virtude não é o elemento que mais se honra, é impossível que os seus cidadãos sejam guiados de modo infalível conforme a própria virtude $^{104}$. Em outras palavras, a honra é indispensável para o bem viver e, portanto, para a própria felicidade. Por isso, para o mestre dominicano, quem mais participa nas honras da cidade pode ser considerado cidadão em sentido pleno (e não um estrangeiro) ${ }^{105}$.

A dulia, como virtude social, tem obviamente um papel social. Sobretudo ao demonstrar que determinado indivíduo ou ação devem ser considerados referência pela sociedade ou para uma comunidade de pessoas. Por exemplo, o doutorado honoris causa (literalmente, "em razão da honra") é concedido por universidades (de praxe, consultando a Academia) a pessoas que

\footnotetext{
${ }^{101}$ Cf. Ad secundum dicendum quod, sicut Philosophus ibidem dicit, honor non est sufficiens virtutis praemium, sed nihil potest esse in humanis rebus et corporalibus maius honore: inquantum scilicet ipsae corporales res sunt signa demonstrativa excellentis virtutis. Est autem debitum bono et pulchro ut manifestetur, secundum illud Matth. V: Neque accendunt lucernam et ponunt eam sub modio, sed super candelabrum, ut luceat omnibus qui in domo sunt: Et pro tanto praemium virtutis dicitur honor. (ST, $\mathrm{II}^{\mathrm{a}} \mathrm{II}^{\text {ae }}$, q. 103, a. 1, ad 2, Leon. 9, p. 377b).

${ }^{102}$ Ad tertium dicendum quod magnificus etiam dat dona vel exennia, ut dicitur in IV Ethic. non tamen sub ratione doni, sed potius sub ratione sumptus ordinati ad aliquod opus faciendum, puta ad honorandum aliquem, vel ad faciendum aliquid unde proveniat honor toti civitati, sicut cum facit aliquid ad quod tota civitas studet. (ST, $\mathrm{II}^{\mathrm{a}} \mathrm{II}^{\text {ae }}$, q. 134, a. 3, ad 3, cit. completa, Leon. 10, p. 93b).

${ }^{103}$ Cf. Sed contra est quod philosophus dicit, in I Rhet. (cap. 9, n. 6) quod maximae virtutes sunt quae aliis maxime sunt utiles, et propter hoc, fortes et iustos maxime honoramus. (ST, $\mathrm{II}^{\mathrm{a}} \mathrm{II}^{\mathrm{ae}}$, q. 141 , a. 8, s.c., Leon. 10, p. 131b).

${ }^{104} \mathrm{Cf}$. Et in quacumque ciuitate uirtus non maxime honoratur, ut scilicet soli uirtuti honor principatus deferatur, impossibile quod in tali ciuitate homines secundum uirtutem infallibiliter principentur. (In Pol., II, 1. 16, n. 7, Leon. 48, p. A178:165-168).

${ }^{105}$ Cf. Maxime ille dicitur ciuis in qualibet politia qui participat honoribus ciuitatis. (In Pol., III, 1. 4, n. 6, Leon. 48, p. A199:141-143).
} 
se destacaram em diferentes campos do saber. Dessa forma, fica consignada para todos a dignidade merecida e a excelência a ser buscada.

Não é infrequente, porém, que esses títulos sejam retirados de seus titulares, por motivos graves, precisamente para não desonrar aqueles que os detêm honestamente. $\mathrm{O}$ inverso também ocorre: o deferimento em recebê-los por algum motivo ético ou pessoal (Sartre, por exemplo, se negou a receber o Nobel de literatura). Ainda no âmbito acadêmico, muitas instituiçôes adotam diferentes níveis de honorificência para a graduação (por exemplo: summa cum laude, magna cum laude, cum laude). Por fim, isso traz uma espécie de "status" ou glória. Ora, esta nada mais é do que uma consequência da honra, que é a sua causa. E esse é um dos motores da honra, ou seja, tornar-se "ilustre" aos olhos dos demais ${ }^{106}$. A glória tem um efeito muito importante, pois evidencia aquela razão que a honra quer atribuir ao sujeito. Donde definir Ambrósio de Milão que a glória é "um conhecimento claro com louvor" ${ }^{107}$. Se a honra é, pois, o ornato da virtude, a glória é o ornato da honra.

\section{Conclusão}

Conforme se abordou, a dulia é uma virtude muito importante para a vida social. De uma parte, é um sinal obrigatório de justo reconhecimento por parte daquele que honra, bem como uma merecida dignidade para quem é honrado, além de modelo de virtude para toda a comunidade. Como "prêmio da virtude”, dela a honra está bem próxima. $\mathrm{Na}$ realidade, sem as honras a virtude não teria todo seu esplendor.

Muitas vezes a ambição pode de fato deslustrar o legítimo desejo das honras. Conforme o pensamento tomasiano, somente a felicidade deve ser buscada pelos homens. Contudo, as honras podem ser almejadas como bem anexo à felicidade, conquistada pela posse das virtudes. $\mathrm{Na}$ verdade, quem busca a honra pela honra, não terá nem sequer a honra, porque isso já seria uma desonra... Aqui cabe precisamente o exercício de outras virtudes: de uma parte, a magnanimidade em reconhecer com equilíbrio as honras e a

\footnotetext{
${ }^{106} \mathrm{Cf}$. Ad secundum dicendum quod laus et honor comparantur ad gloriam, ut supra dictum est, sicut causae ex quibus gloria sequitur. Unde gloria comparatur ad ea sicut finis, propter hoc enim aliquis amat honorari et laudari, inquantum per hoc aliquis aestimat se in aliorum notitia fore praeclarum. $\left(S T, \mathrm{II}^{\mathrm{a}} \mathrm{II}^{\mathrm{ae}}\right.$, q. 132, a. 4, ad 2, Leon. 10, p. 83b).
}

${ }^{107}$ AMBRÓSIO. Ordin. Super Rom. 16, 27 apud ST, $\mathrm{II}^{\mathrm{a}} \mathrm{II}^{\mathrm{ae}}$, q. 103, a. 1, ad 3. 
humildade em não as desejar futilmente. Com efeito, a ambivalência honra/ vergonha se torna com frequência a nossa régua ética na tomada de decisões.

A questáo da dulia, como virtude, exclui a sua abrangência no quadro do que hoje se chama "culto à personalidade". De uma parte, a autêntica honra só é prestada pelos virtuosos aos virtuosos, como testemunho de suas virtudes. Ora, onde há autoritarismo, narcisismo, adulação, etc. não pode haver virtude. Por isso, não se pode confundir dulia com a expressão acima cunhada por Nikita Khrushchev.

Isso considerado, não se deve temer em honrar. Antes, como foi evidenciado, é um dever manifestar o bem e o belo das virtudes. Elas são essenciais para se ressaltar a própria excelência humana. Honrar, sem dúvida, é um dos atos mais nobres da alma humana, pois a dignifica e a aperfeiçoa. Quem honra é de alguma forma honrado (ou ao menos dignificado), porque se torna ainda mais virtuoso pelo exercício da dulia.

O positivismo exacerbado, segundo o qual o homem age sempre por interesse próprio, finca o sentido completamente falho e contrário aos próprios anseios de uma sociedade onde as virtudes devem resplandecer a todos. A honra é propriamente este esplendor da virtude. Nessa esteira, a proposta tomasiana traz consigo, antes de tudo, a revalorização da honra, como promoção da virtude e da própria felicidade.

RAMOS, F. A. The virtue of dulia (honor) in Thomas Aquinas. Trans/Form/Ação, Marília, v. 42, p. 265-290, 2019. Edição Especial.

\footnotetext{
ABSTRACT: Honor was amply dealt with by several ancient authors such as Aristotle and Cicero. In the Middle Ages, Thomas Aquinas revisited certain themes from Antiquity, offering new formulations. To do this, he used the concept of dulia, going beyond the traditional contrast with latria. He regards dulia as a virtue connected to justice and that seeks to pay honour or homage to excellent men, particularly virtuous ones. In fact, Aristotle already regarded honour as a "reward for virtue". In this article, the body of Thomistic work is explored in order to analyse the concept of dulia and honour. To this end, it is asked what dulia truly is, to whom it should be rendered, whether honour can or should be desired, what the role of magnanimity is, and how honour should be shown and for what. The Thomistic proposal offers a new outlook on a subject which, unfortunately, has been somewhat neglected in the present day.
}

KeYwords: Dulia. Honour. Magnanimity. Justice. Virtue. 


\section{REFERÊNCIAS}

ARISTÓTELES. Ethica Nicomachea. I. Bywater (ed.). Oxford: Clarendon, 1894 (repr. 1962).

ARISTÓTELES. Rhetorica. W. D. Ross (ed.). Oxford: Clarendon, 1959 (repr. 1964).

ARISTÓTELES. Retórica. Traduçāo: Manuel Alexandre Júnior, Paulo Farmhouse Alberto e Abel do Nascimento Pena. Lisboa: Imprensa Nacional; Casa da Moeda, 2005.

BILLUART, C-R. Summa Sancti Thomae hodiernis academiarum moribus accomodata. Parisiis: Victorem Palmé, 1878. v. 5.

CARPINTEIRO, F. La dignidad humana en Tomás de Aquino. Persona y Derecho, v. 74, p. 97-116, 2016.

CASAGRANDE, C. Entre justice et humilité. Les vertus du respect chez Thomas d'Aquin. Revue des Sciences Philosophiques et Théologiques, v. 101, n. 2, p. 219-238, 2017.

CICERO, M. T. De inventione. In: On Invention. The Best Kind of Orator. Topics. Translated by H. M. Hubbell. Loeb Classical Library 386. Cambridge, MA: Harvard University Press, 1949.

CICERO, M. T. Brutus. In: Brutus. Orator. Translated by G. L. Hendrickson, H. M. Hubbell. Loeb Classical Library 342. Cambridge, MA: Harvard University Press, 1939.

FRANCISCO DE VICTORIA. Comentarios a la Secunda Secundae de Santo Tomás. Tomo V: De iustitia et fortitudine. Vicente Beltrán de Heredia (ed.). Salamanca, 1937.

GAUTHIER, R. A. Magnanimité: l'ideal de la grandeur dans la philosophie païenne et dans la théologie chrétienne. Paris: Vrin, 1951.

HORNER, D. What it takes to be great: Aristotle and Aquinas on magnanimity. Faith and Philosophy, v. 15, p. 415-444, 1998.

JACOTOT, M. Question d'honneur: les notions d'honos, honestum et honestas dans la République Romaine Antique. Rome: École française de Rome, 2013.

KROM, M. P. Civic virtue: Aquinas on piety, observance, and religion. Proceedings of the American Catholic Philosophical Association, v. 88, p. 145-153, 2014.

OLIVEIRA, T. Thomas Aquinas and social virtues of piety and respect: an outlook of the history of education. Acta Scientiarum: Education, v. 35, p. 17-25, 2013.

OLSTHOORN, P. Honor as a motive for making sacrifices. Journal of Military Ethics, v. 4, p. 183-197, 2005.

OLSTHOORN, P. Honor in political and moral philosophy. Albany: State University of New York Press, 2015.

PHILIPPUS CANCELLARIUS. Summa de bono. Nikolaus Wicki (ed.) Corpus Philosophorum Medii Aevi. Bernae: Francke, 1985. 2 v. 
PLATO (Platão). Respublica. J. Burnet (ed.). Platonis opera, vol. 4. Oxford: Clarendon Press, 1902. (repr. 1968).

PUBLILIUS SYRUS. Sententiae. In: DUFF, J. W.; DUFF, A. M. (ed.). Minor Latin Poets, v. 1. Loeb Classical Library 284. Cambridge, MA: Harvard University Press, 1934.

ROBIGLIO, A. A. Aquinas on recognition. In: KAHLOS, M.; KOSKINEN, H. J.; PALMÉN, R. (ed.). Recognition and religion: contemporary and historical perspectives. Oxford; New York: Routledge, 2019. p. 168-179.

SOKOLOWSKI, R. Honor, anger, and belittlement in Aristotle's Ethics. Studia Gilsoniana, v. 3, p. 221-240, 2014.

TARÁN, L. Amicus Plato sed magis amica veritas. From Plato and Aristotle to Cervantes. Antike und Abendland, v. 30, p. 93-124, 1984.

THOMAS DE AQUINO. Opera omnia. Editio Leonina (= Leon.):

THOMAS DE AQUINO. Summa theologiae cum Supplemento et commentariis Caietani. Romae, 1888-1906. v. 4-12.

TOMÁS DE AQUINO. Suma teológica. Tradução: Carlos-Josaphat P. de Oliveira et al. São Paulo: Loyola, 2001-2006. 9 v. (= ST).

THOMAS DE AQUINO. Summa contra Gentiles cum commentariis Ferrariensis. Romae, 1918-1930. v. 13-15. (= SCG).

THOMAS DE AQUINO. Quaestiones de quolibet I-XII. Roma; Paris, 1996. v. 25, 1-2. $(=Q Q)$.

THOMAS DE AQUINO. Sententia libri Ethicorum. Romae, 1969. v. 47, 1-2. (= In Eth.).

THOMAS DE AQUINO. Sententia libri Politicorum. Romae, 1971. v. 48. (= In Pol.).

THOMAS DE AQUINO. Scriptum super libros Sententiarum Magistri Petri Lombardi Episcopi Parisiensis. P. MANDONNET; M. F. MOOS (eds.). Paris, 1929-1947 (usque ad lib. IV, d. 22) (= Mand.). (= In Sent.).

THOMAS DE AQUINO. Scriptum super libros Sententiarum Magistri Petri Lombardi Episcopi Parisiensis. R. BUSA (ed.). Opera omnia: ut sunt in indice thomistico additis 61 scriptis ex aliis medii aevi, 7 vol., Index Thomisticum sect. IV.1, Stuttgart; Bad Cannstatt, 1980 (ab lib. IV, d. 23 usque ad finem). (= In Sent.).

VARRO, M. T. De lingua latina quae supersunt. Georg Goetz; Fritz Schöll (eds.). Amsterdam: A.M. Hakkert, 1964.

WALTHER, H. Lateinische Sprichwörter und Sentenzen des Mittelalters in alphabetischer Anordnung. 1-V, Göttingen: Vandenhoeck \& Ruprecht, 1963-1967.

Recebido: 30/12/2019

Aceito: 30/12/2019 
RAMOS, F. A. 